Boston University School of Law Scholarly Commons at Boston University School of Law

Faculty Scholarship

2012

\title{
The 'Justice Deficit' Debate in EU Private Law: New Directions
}

Daniela Caruso

Boston Univeristy School of Law

Follow this and additional works at: https://scholarship.law.bu.edu/faculty_scholarship

Part of the European Law Commons, and the Law and Economics Commons

\section{Recommended Citation}

Daniela Caruso, The 'Justice Deficit' Debate in EU Private Law: New Directions, No. $12-42$ Boston University School of Law, Public Law Research Paper (2012).

Available at: https://scholarship.law.bu.edu/faculty_scholarship/590 


\section{BU School of Law}

\section{The ‘Justice Deficit’ Debate in EU Private LAW: NEW DIRECTIONS}

Boston University School of Law Working Paper No. 12-42

(August 23, 2012)

Daniela Caruso

Boston University School of Law

This paper can be downloaded without charge at:

http://www.bu.edu/law/faculty/scholarship/workingpapers/2012.html 
Daniela Caruso $^{1}$

The 'Justice Deficit' Debate in EU Private Law: New Directions ${ }^{2}$

This essay outlines the ongoing debate on the justice deficit of EU private law -the 'social justice' debate - and then points at an underexplored avenue of inquiry that is essential for this debate to stay meaningful and constructive. Future research should aim to calibrate EU private law to the socio-economic asymmetries of the EU market, and to counterbalance the uneven weight of uniform rules, where they appear desirable, with proper compensatory mechanisms.

1. EU Private Law and the Social Justice Critique - The start of private law harmonization at a supranational level can be conventionally identified with the enactment of the EEC Directive on Products Liability in 1985. At that point in time, the project could be characterized as one of convergence between the goal of market harmonization and the goal of promoting social justice throughout Europe. ${ }^{3}$ The directive was inspired by the parallel work of the Council of Europe on the same subject. The thalidomide children, by then come of age, brought to everyone's attention the need to redraft the laws of product liability in a way that would induce producers to engage in ethical manufacturing. The directive was intended by many as a progressive response to corporate excesses. To be sure, the directive also pursued the competition goal of leveling the playing field for all manufacturers, forcing them to internalize the same amount of liability costs everywhere in the market, in Germany as in Greece. But social justice and market goals seemed to go perfectly together, as if they were two sides of one (valuable) coin.

Over time, however, things proved to be quite different. First, producers' lobbies used the national processes of transposition as an opportunity to carve out important exceptions to strict product liability. Then, in 2002, the Court of Justice of the EU interpreted the directive as preemptive of more consumer-friendly national rules. ${ }^{4}$ As a result, the initial 'embedding' of tort law into the social problem of dangerous products by virtue of European legislation turned into its opposite: a supranational institution forcibly dis-embedding product liability from the socially conscious fabric of national private laws. ${ }^{5}$

Today, the project of building the market through private law harmonization continues unabated, especially in contract law matters. The Commission would certainly like to go back to those halcyon days when it seemed possible to do both things at once: give the internal market uniform rules and, in one stroke, click into synch with the dominant social consciousness of member states' constituencies. To that goal, the Commission has recently drafted a proposal for a

\footnotetext{
${ }^{1}$ Boston University School of Law.

${ }^{2}$ Essay prepared for the Colloquium "Europe's Justice Deficit? Beyond Good Governance," London School of Economics, September 22-23, 2012.

${ }^{3}$ Christian Joerges and Christoph Schmid, Towards Proceduralization of Private Law in the European Multi-Level System, in Towards a European Civil Code, $4^{\text {th }}$ edition, 277, 294 (2011).

${ }^{4}$ Case C-183/00, González Sánchez v. Medicina Asturiana (2002).

${ }^{5}$ Joerges and Schmid, supra, at 295.
} 
Common European Sales Law (CESL) that contains a number of pro-consumer rules for B2C transactions. The proposed CESL is at the same time a step towards cross-border uniformity (for those parties who decide to opt for this instrument in their transactions) and a piece of regulation meant to redress the bargaining imbalance of individual buyers. The list of the limits to private autonomy enumerated in the CESL is long enough as to displease libertarian commentators, ${ }^{6}$ but it fails, nonetheless, to assuage the skepticism of socially oriented scholars. In EU private law the skeptics argue - justice is thin. ${ }^{7}$ The current acquis of supranational private law might promote access for all, including persons traditionally unable to take advantage of market opportunities, ${ }^{8}$ but its focus on access (essentially a procedural aspect) makes it inherently indifferent to substantive distributive outcomes and therefore in tension with the variously 'embedded' private laws of the member states.'

The social justice critique of EU private law has gone even further, launching an external attack on the very idea of an internal market and on its inherent commodification of all things human. Here is an example of this type of criticism. The adoption of uniform rules for on-line sales of goods is supposed to increase consumer choice, facilitate the comparison of transparent terms and product details, foster healthy competition among manufacturers, etc. The fact is, however, that on-line purchases from distant locations will result in increased transport and larger carbon footprints; delivery at one's door-steps will disrupt the salutary habit of getting out of one's dwelling and heading to the shopping mall - the modern-day public forum; etc. The success of on-line markets is, by this account, a loss for Planet Earth and for human interaction. It is, moreover, the kind of loss that finds no blessing in any form of democratic endorsement. ${ }^{10}$

2. The New Constructive Turn of the Social Justice Debate - These days, within the social justice camp, a less critical and more constructive strand is making strides. Its faith in EU private law is to be found in anti-nationalist politics. ${ }^{11}$ The revival of xenophobic trends within the European polity has many social-justice scholars deeply worried about the motivations of Euroskeptics in private law camps. Opposition to an EU code is in their eyes a symptom of parochialism and fear of 'the other.' 12 The defense of a state's own civil code (once explainable in light of multiple causes, including social justice concerns) has begun to look like a crusade of nationalist identity

\footnotetext{
${ }^{6}$ See e.g. Richard Epstein, Harmonization, Heterogeneity and Regulation: Why the Common European Sales Law Should Be Scrapped, _ Common Market L. Rev. _ (2012).

${ }^{7}$ Hugh Collins, Cosmopolitanism and Transnational Private Law, 8 Eur. Rev. Contract L. 311 (2012) (positing that "European Union private law relies for its legitimacy almost entirely on its pursuit of a thin theory of justice concerning the enhancement of individual choice, which inevitably brings it into conflict with national private law systems that pursue broader schemes of social justice.")

${ }^{8}$ Hans-W. Micklitz, Introduction, in: Hans-W. Micklitz ed., The Many Concepts of Social Justice in European Private Law 3 (2011).

${ }^{9}$ Chantal Mak, In Defence of CESL, _ Common Market L. Rev. _ (2012).

${ }^{10}$ Marija Bartl, Legitimacy and European Private Law 2012, Doctoral Thesis, EUI (on file with author).

${ }^{11}$ Martijn Hesselink, The case for a common European sales law in an age of rising nationalism, 8 Eur. Rev. Contract L. 342 (2012).

${ }^{12}$ Ruth Sefton-Green, French and English crypto-nationalism and European private law, 8 Eur. Rev. Contract L. 260 (2012).
} 
against influxes of foreign ideas and persons. ${ }^{13}$ In this light, a supranational project of private law harmonization becomes a bulwark of pluralism and inclusion - the ultimate social-justice manifesto. This strand of the social-justice debate is therefore molding its critique into a purposeful set of recipes to fix what is currently broken in the Commission's private law agenda.

The first and by now well-known recipe has to do with democracy. In 2004, while a draft EU Constitution was being finalized for the peoples of Europe, Martijn Hesselink compiled a list of private-law questions to be submitted to national parliaments, so as to enhance the transparency and legitimacy of the EU codification project. ${ }^{14}$ Several scholars joined in the plea for more openness and inclusion in the process of private law harmonization. Some work had already been done to dispel the resilient assumption that private law was technical, a-political, and inconsequential on distributive grounds. ${ }^{15}$ Further effort was put into opening the Commission's harmonization methods to multiple inputs from private law scholars and stakeholders. The Commission listened and developed participatory mechanisms, oftentimes co-opting private law scholars of various political persuasions into the process so as to have multiple views represented in its expert groups. To be sure, it is not clear that the process, in its present state, can be deemed democratic in any serious sense, but there is no question that the harmonization of private law no longer happens behind closed doors in Brussels. A stronger reason to doubt the democracy fix is that participatory input, per se, cannot lead to socially just laws in the absence of clearly identified substantive criteria of distributive justice.

The second type of constructive critique comes from linkages between civil codes and constitutional law. To certain scholars invested in the social justice debate, the process of private law harmonization needs to be infused with constitutional theory - in particular, with constitutional pluralism. ${ }^{16}$ The suggestion is that private law harmonization of the soft type (as exemplified by the CESL's optional nature) is indeed desirable, because it allows for the existence of different suborders of private law, and yet contributes to the realization of a legalpolitical community based on supranational or cosmopolitan values (such as the protection of weaker parties in market transactions).

The third fix, steeped in the German tradition of Drittwirkung, involves fundamental rights. ${ }^{17}$ The argument for placing human rights at the heart of EU private law gained strength after the entry into force of the Lisbon Treaty, which elevated the Nice Charter to the status of primary

\footnotetext{
${ }^{13}$ Ralf Michaels, Code vs Code, 8 Eur. Rev. Contract L. 277 (2012) (characterized the resistance to the EU civil code on the part of national civilistes as a form of religious war).

${ }_{15}^{14}$ Martijn Hesselink, The Politics of a European Civil Code, 10 Eur. L. J. 675 (2004).

${ }^{15}$ See e.g. David Kennedy, The Methods and Politics of Comparative Law, in Mauro Bussani and Ugo Mattei eds., The Common Core of European Private Law: Essays on the Project 131 (2003); and Daniela Caruso, The Missing View of the Cathedral: The Private Law Paradigm of European Legal Integration, 3 Eur. L. J. 3 (1997).

${ }^{16}$ Chantal Mak, Europe-building through private law. Lessons from constitutional theory, 8 Eur. Rev. Contract L. 326 (2012).

${ }^{17}$ Hugh Collins, The Impact of Human Rights Law on Contract Law in Europe, 4 Eur. Business L. Rev. 425 (2011); Chantal Mak, Europe-building, supra.
} 
legislation. The hope was that such fundamentals as the right to collective bargaining would counteract the socially devastating force of the Treaty's market freedoms. The possibilities of this approach are yet to be explored, but chances are that the principled strength of the charter will be neutralized by the CJEU's increasingly refined 'balancing' jurisprudence.

3. Regulation as Laissez Faire - A fourth recipe for improving the social justice aspect of EU private law is in the process of being articulated ${ }^{18}$ and has not, as yet, coalesced into a manifesto or school of thought. This recipe may or may not bring fuel for the further supra-nationalization of private law, but it would certainly enhance the quality of ongoing market studies and perhaps correct the troublesome strand of CJEU private-law jurisprudence exemplified by Gonzáles Sánchez (2002). This line of inquiry, which openly espouses redistribution as a plausible (and in fact ineluctable) component of private law - aims to bring to the table not just a universal concept of justice, but specific evidence of the uneven impact of uniform private law rules on divergent socio-economic realities. Regrettably, real differences have so far failed to inform the private law harmonization process. The empirical studies conducted by the Commission with regard to consumer preferences, on-line dealings, and purchase patterns have ignored such crucial facts as (a) the superiority of western brands in the eyes of eastern consumers, which allows western traders to segment markets and 'dump' their goods in the EU periphery; ${ }^{19}$ (b) the one-way flow of manufacturing to Central and Eastern Europe (CEE), which means that "local" shopping equals, in the periphery, to buying Western products possibly dumped on their markets; ${ }^{20}$ (c) the poor transport infrastructure that hinders delivery of on-line purchases in certain regions of Europe more than in others; ${ }^{21}$ etc. This is how a scholar certainly familiar with such realities describes the impact of European contract terms regulation upon budding CEE entrepreneurs:

"The level of protection is exceedingly high. [...] The costs imposed in particular on small businesses by complying with these often excessive and sometimes unclear standards and rules should not be underestimated. If assiduously applied, the results may be devastating for both employment and business. However, such concerns are apparently not shared by the Commission. The Regular Progress reports generally follow formal indicators of enforcement, and praise high numbers of checks and penalties." 22

\footnotetext{
${ }^{18}$ See e.g. Fernanda Nicola, Invisible Cities in Europe, 35 Fordham Int'l L.J. 1282 (2012).

${ }^{19}$ Damjan Kukovec, A Critique of the Rhetoric of Common Interest in the European Union Legal Discourse (2012), http://www.harvardiglp.org/new-thinking-new-writing/a-critique-of-rhetoric/.

${ }^{20}$ Jared Salter, From Karl Marx to Trademarks (2006), http://www.brandchannel.com/brand speak.asp?bs_id=140 (last visited August 16, 2012).

21 See e.g. Consumer Conditions Scoreboard, 7th Edition, May 2012, available at http://ec.europa.eu/consumers/consumer_research/editions/cms7_en.htm.

${ }^{22}$ Antonina B. Engelbrekt, The Impact of EU enlargement on private law governance in Central and Eastern Europe: the case of consumer protection, in Fabrizio Cafaggi and Horatia Muir-Watt eds, Making European Private Law: Governance Design 98 (2010).
} 
Interestingly, the Commission is not alone in showing indifference to such concerns. In the Czech Republic, for example, the government has flaunted a 'highly positive attitude' towards the full harmonisation of consumer law. ${ }^{23}$ This does not mean, however, that the costs associated with maximal consumer contract regulation are risible or irrelevant. More probably, signing onto a uniform degree of consumer protection performs a necessary signalling function: it conveys familiarity with contemporary business practices, comfort with the state of the art, and willingness to compete on a level playing field. A state busy catching up with old member states must signal its readiness, and has no choice but to jump onto a regulatory bandwagon already moving at full speed.

A realist, empirically informed inquiry on the varied impact of uniform market rules has become crucial in the aftermath of a set of CJEU decisions (Viking ${ }^{24}$ et al.), all concerning significant wage differentials among workers in western and CE Europe. No one on the left of the political spectrum would ever object to the idea of redistributing some wealth from healthier economies to the periphery of the Union. What is upsetting is that the particular redistribution enabled - say by the Viking decision moves wealth from the workers of State A to the worse-off workers of State B, and at the same time allows the employers of State A to stay in profitable business. In so far as, within State A, employers as a class are better off than workers, the type of redistribution enabled by Viking is starkly regressive. ${ }^{25}$ Viking's deregulatory effects, seemingly virtuous on distributive grounds, fail the realist test in a multi-state context.

The time is ripe for asking similar questions in the context of private law harmonization. Just like Viking's endorsement of economic freedom for businesses, the imposition of uniform regulatory constraints may actually steer wealth away from the wrong place. Imagine, for instance, the following simple scenario: as a result of uniform sales rules, sellers in State B become subject to the same degree of costs as sellers in State A, but their ability to pass on these costs to consumers is much lower: their brands - given consumer biases - are less appealing; if they charged higher prices, consumers would not buy from them. Their margin of profit is thereby reduced, and would only be made up by a higher sales volume if consumers truly valued the increase in postsale remedies caused by the new law (an effect that cannot be taken for granted). In the end, consumers everywhere may be better off, but the sellers who have contributed to consumers' overall welfare are those of State B only. In so far as they are, by definition, of low economic status vis-à-vis sellers in State A, the transfer of wealth that derives from sales law uniformity is of the regressive type.

\footnotetext{
${ }^{23}$ Thomáš Břicháček, Some remarks on the Proposal of a Directive on Consumer Rights, in Hans Schulte-Nölke and Luboš Tichý eds., Perspectives for European Consumer Law: Towards a Directive on Consumer Rights and Beyond 97 (2010).

${ }^{24}$ C-438/05 International Transport Workers Federation v. Viking Line ABP (2007).

${ }^{25}$ Alexander Somek, From workers to migrants: Exploring the changing social-democratic imagination, NYU 2012 (on file with author).
} 
Just as we duly question, in theory and in practice, the distributive effects of such pro-market rulings as Viking, we should investigate the distributive impact of pro-consumer rules. The imposition of uniform contract laws meant to protect the weaker party might seem, conceptually, the opposite of market freedom, and it is, indeed, regulatory in nature - the sort of regulation that counts on the enforcement of public rules through private litigation. ${ }^{26}$ In this context, however, regulation and market freedom must be handled with equal caution. The uniform regulation of contact law throughout a socio-economically diverse market shares, in fact, a fundamental feature of laissez faire - namely, its indifference by design to the socioeconomic diversity of the market. Ironically, member states experienced the progressive socialization and embedding of their private laws in the $20^{\text {th }}$ century, but the EU is now reviving the nineteenth-century habit of insulating the law of private autonomy from the larger question of systemic inequality. ${ }^{27}$

4. The Way Forward - Empirical studies need to be refined and theoretical models need to be formulated in light of the structural asymmetries of the European landscape. ${ }^{28}$ If regressive effects emerge at any step of private law harmonization, the current harmonization strategy must be revisited. Conscious of these dynamics, some scholars have considered shifting from uniform rules to a much looser system of coordination among different private law systems within a procedural 'conflicts' model, ${ }^{29}$ and it is plausible that, on a case-by-case basis, this may turn out to be the best possible option. This is not, however, the only way out of regressive predicaments. It may still be the case that certain EU-wide contract rules should be put into place to reflect uniform values such as the protection of weaker parties or the sanctity of post-sale remedies. It may be necessary, however, to include in the architecture of reform elements of compensation or reparation for those who stand to lose disproportionately from an otherwise desirable regulatory intervention. The template for such reparations is to be found in the rich economic and philosophical foundations of systems theory, postcolonial studies and development economics. Just like the harmonization of private law rules, but on a much larger scale, the stipulation of world-wide labor and environmental standards may impose heavier burdens on developing countries. It is important to be cognizant of such burdens in designing uniform rules, not because they should be scrapped, but rather because they should be embedded in comprehensive, and compensatory, trade or transfer regimes. ${ }^{30}$

\footnotetext{
${ }^{26}$ Andrei Shleifer, Understanding Regulation, 11 European Financial Management 439, 445 (2005).

${ }^{27}$ Florian Rödl, 'Private Law, Democracy, Codification. A Critique of the European Law Project', in Christian Joerges and Tomi Ralli eds., European Constitutionalism without Private Law. Private Law without Democracy, RECON Report No 14, ARENA Report 3/11 (Oslo, 2011) 141, 151.

${ }^{28}$ Somek's analyisis of Viking (supra) is a clever example of such modeling.

${ }^{29}$ Joerges and Schmid, supra, at 295 ("The [Commission's strategy of full harmonization] is at odds with the socioeconomic diversity which persists, and is even deepening, in Europe. In view of this diversity, the imposition of uniform rules on the balancing of market development and consumer demand do not make economic sense. They also risk the destruction of the social fabric of markets and consumption which remains ... in important respects characterized by national contexts.")

${ }^{30}$ A conceptual model for such compensatory mechanisms can be found e.g. in generalized systems of preferences conditioned on compliance with common international labor standards. See Michael J. Trebilcock and Robert Howse, The Regulation of International Trade, $3^{\text {rd }}$ edition, 2005, at 574.
} 